\title{
MOTIVASI DAN KOMPETENSI BERPENGARUH TERHADAP KINERJA PEGAWAI KANTOR PELAYANAN PAJAK PRATAMA
}

Oleh:

\author{
Umi Sartika
}

Fakultas Ekonomi Universitas Kader Bangsa

Jalan Mayor Ryacudu 88 Palembang

\begin{abstract}
The purpose of this research is to know the influence of motivation and competence to employee performance of Tax Service Office Pratama Prabumulih. Population of this research as many as 72 employees and the data was obtained from 58 respondent in Tax Service Office Pratama Prabumulih. The analysis which used in this research is multiple linier regression analysis, $F$ test and t test. The result of calculations using SPSS, showed that: determinant coeficient of 0.166 or $16.6 \%$, illustrates that performance of employees $(Y)$, can be explained by motivation and competence $16.6 \%$, while the remaining $83.4 \%$ can be explained by other factor which are not include in this study. From the result hypothesis F test, obtained value of Fcompute (5.460)> Ftable (2.78), means that there is the influence of motivation and competence together to employee performance. While result of the hypothesis $t$ test, showed that application of motivation and competence partially had influence to employee performance of Tax Service Office Pratama Prabumulih.
\end{abstract}

Key word: motivation, competence, employee performance

\section{PENDAHULUAN}

Aset yang penting dalam suatu perusahaan untuk mencapai tujuan dari perusahaan adalah sumber daya manusia yang terdapat di dalam perusahaan tersebut. Pimpinan perusahaan bertanggung jawab atas sumber daya manusia atau karyawan yang bekerja pada perusahaannya. Siklus operasi perusahaan berada pada karyawan yang bekerja, jika karyawan memberikan produktivitas yang tinggi maka perusahaan akan mencapai tujuan yang di inginkan, namun sebaliknya jika produktivitas karyawan rendah maka perusahaan akan sulit mencapai tujuanyang telah ditetapkan. Produktivitas karyawan dipengaruhi oleh beberapa faktor antara lain motivasi, perilaku, keterampilan, kedisiplinan dan kompetensi yang dimilki oleh karyawan. 
Kantor Pelayanan Pajak Pratama Prabumulih merupakan instansi milik negara yang bertugas memungut pajak dari masyarakat untuk di setorkan ke kas negara. Pajak merupakan sumber penghasilan utama bagi kas negara yang mendukung laju pertumbuhan ekonomi negara. Untuk itu sumber daya manusia yang berada pada Kantor Pelayanan Pajak Pratama Prabumulih harus berkualitas agar dapat melaksanakan tugasnya dengan baik.

Kualitas sumber daya manusia pada Kantor Pelayanan Pajak Pratama Prabumulih dilihat dari tingkat pendidikan adalah sebagai berikut :

Tabel 1.Data Pegawai Kantor Pelayanan Pajak Pratama Prabumulih Berdasarkan Tingkat Pendidikan

\begin{tabular}{clcc}
\hline No & Pendidikan & Jumlah & Persentase (\%) \\
\hline 1 & S2 Manajemen & 10 & 13,89 \\
2 & S2 Hukum & 1 & 1,389 \\
3 & S2 Administrasi Perpajakan & 1 & 1,389 \\
4 & S1 Ekonomi & 5 & 6,94 \\
5 & S1 Akuntansi & 8 & 11,11 \\
6 & S1 Manajemen & 8 & 11,11 \\
7 & S1 Komputer & 1 & 1,389 \\
8 & DIV Perpajakan & 4 & 5,56 \\
9 & DIII Perpajakan & 15 & 20,83 \\
10 & DIII Akuntansi & 8 & 11,11 \\
11 & DI & 5 & 6,94 \\
12 & SMA & 6 & 8,33 \\
\hline \multicolumn{2}{r}{ Jumlah } & $\mathbf{7 2}$ & $\mathbf{1 0 0}$ \\
\hline
\end{tabular}

Sumber : Kantor Pelayanan Pajak Pratama Prabumulih, tahun 2015

Berdasarkan tabel di atas, dapat dilihat bahwa pendidikan yang dimiliki pegawai Kantor Pelayanan Pajak Pratama Prabumulih tersebut cukup tinggi atau telah mengimbangi dengan kemampuan teknis yang diinginkan oleh institusi. Para pegawai telah memahami prosedur kerja yang berlaku dan mampu melaksanakan tugas kepegawaian dengan sebagaimana mestinya. Hal tersebut dikarenakan para pegawai berasal dari alumni Sekolah Tinggi Akuntansi Negara (STAN), sehingga memiliki pendidikan dan keahlian yang sesuai dengan bidang pekerjaannya yaitu pegawai pajak, yang bernaung dibawah Kementerian Keuangan Negara Republik Indonesia. Namun pekerjaan yang monoton setiap harinya dan bagi pegawai pada seksi-seksi tertentu seperti; seksi pengawasan dan konsultasi, seksi ekstensifikasi dan penyuluhan, seksi penagihan dan fungsional pemeriksa harus bekerja sesuai target agar wajib pajak dapat menyetor pajak ke kas Negara sesuai dengan target yang telah ditentukan. Hal tersebut 
menimbulkan kejenuhan bahkan cenderung kegelisahan bagi pegawai pajak jika tidak bisa memenuhi target, yang berdampak pada kinerja pegawai pajak, padahal pegawai tersebut telah berusaha seoptimal mungkin dalam memenuhi target tersebut bahkan harus menjalankan dinas luar kota untuk menemui wajib pajak seperti ke Muara Enim, Tanjung Enim, PALI dan kabupaten kota lainnya. Ketika pegawai tersebut dinas luar dan tiba di kediaman wajib pajak maka tidak jarang menemui kesulitan seperti wajib pajak tersebut tidak dapat ditemui, wajib pajak memberikan data fiktif tentang usahanya, bahkan ada pegawai pajak yang harus berhadapan dengan preman-preman yang merupakan suruhan dari wajib pajak untuk menghindari petugas pajak yang datang. Hal itu terkadang menyebabkan pegawai pajak pulang ke kantor dengan tangan kosong dan perjalanan dinas tersebut sia-sia.

Berikut ini disajikan rekapitulasi data usia Pegawai Kantor Pelayanan Pajak Pratama Prabumulih.

Tabel 2. Data Usia Pegawai Kantor Pelayanan Pajak Pratama Prabumulih

\begin{tabular}{cccc}
\hline No & Tingkat Usia & Jumlah & Persentase \\
\hline 1 & $20-29$ tahun & 27 & 37,5 \\
2 & 30-39 tahun & 24 & 33,3 \\
3 & $40-49$ tahun & 13 & 18,05 \\
4 & 50-59 tahun & 8 & 11,11 \\
\hline & Jumlah & $\mathbf{7 2}$ & $\mathbf{1 0 0}$
\end{tabular}

Sumber : Kantor Pelayanan Pajak Pratama Prabumulih, tahun 2015

Berdasarkan tabel di atas dapat dilihat bahwa 37,5\% Pegawai Kantor Pelayanan Pajak Pratama Prabumulih berada pada tingkat usia 20 - 29 tahun. Hal itu menunjukkan bahwa pegawai Kantor Pelayanan Pajak Pratama Prabumulih berusia produktif. Menurut UU No. 13 tahun 2003 Bab I pasal 1 ayat 2 disebutkan bahwa tenaga kerja adalah setiap orang yang mampu melakukan pekerjaan guna menghasilkan barang atau jasa baik untuk memenuhi kebutuhan sendiri maupun untuk masyarakat.Batas usia kerja produktif yang berlaku di Indonesia adalah berumur 15 tahun - 64 tahun. Menurut pengertian ini, setiap orang yang mampu bekerja disebut sebagai tenaga kerja.

Berdasarkan latar belakangdi atas, maka peneliti merumuskan beberapa masalah yaitu sebagai berikut:

1. Apakah ada pengaruh motivasi dan kompetensi secara bersama-sama terhadap kinerja pegawai Kantor Pelayanan Pajak Pratama Prabumulih? 
2. Apakah ada pengaruh motivasi dan kompetensi secara parsial terhadap kinerja pegawai Kantor Pelayanan Pajak Pratama Prabumulih?

\section{KERANGKA TEORITIS}

\section{Penelitian Terdahulu}

Penelitian pernah dilakukan oleh Safwa, Nadirsyah \& Abdullah (2014) dengan judul Pengaruh Kompetensi dan Motivasi terhadap Kinerja Pengelolaan Keuangan Daerah pada Pemerintah Daerah Kabupaten Pidie Jaya dimana maksud dari penelitian ini ingin melihat pengaruh kompetensi $\left(\mathrm{X}_{1}\right)$ dan motivasi kerja $\left(\mathrm{X}_{2}\right)$ terhadap kinerja $(\mathrm{Y})$. Dari hasil penelitian dimaksud, diketahui nilai koefisien determinasi sebesar 0.95 atau 95\% yang berarti variabel perubahan kinerja dipengaruhi secara bersama-sama oleh variabel kompetensi dan motivasi. Selain itu juga variabel kompetensi dan motivasi berpengaruh secara parsial terhadap kinerja sebesar 0.160 atau $16 \%$.

Penelitian juga pernah dilakukan oleh Suparno \& Sudarwati (2014) dengan judul Pengaruh Motivasi, Disiplin Kerja dan Kompetensi terhadap Kinerja Pegawai Dinas Pendidikan Kabupaten Sragen dimana dimaksud dari penelitian ini ingin melihat pengaruh motivasi $\left(\mathrm{X}_{1}\right)$, disiplin kerja $\left(\mathrm{X}_{2}\right)$ dan kompetensi $\left(\mathrm{X}_{3}\right)$ terhadap kinerja pegawai (Y). Dari hasil penelitian dimaksud, diperoleh bahwa nilai motivasi (X1) sebesar 0.007 , disiplin kerja $\left(\mathrm{X}_{2}\right)$ sebesar 0.0037 dan kompetensi $\left(\mathrm{X}_{3}\right)$ sebesar 0.000, masingmasing nilai tersebut lebih kecil daripada 0.05 yang berarti bahwa motivasi $\left(\mathrm{X}_{1}\right)$, disiplin kerja $\left(\mathrm{X}_{2}\right)$ dan kompetensi $\left(\mathrm{X}_{3}\right)$ berpengaruh secara parsial terhadap kinerja pegawai $(\mathrm{Y})$. Sedangkan hasil uji $\mathrm{F}$ diperoleh hasil bahwa motivasi $\left(\mathrm{X}_{1}\right)$, disiplin kerja $\left(\mathrm{X}_{2}\right)$ dan kompetensi $\left(\mathrm{X}_{3}\right)$ berpengaruh secara simultan terhadap kinerja pegawai (Y).

\section{Kajian Teori}

\section{Kinerja}

Menurut Sedarmayanti (2007:260) kinerja berarti pencapaian/prestasi seseorang berkenaan dengan tugas yang diberikan kepadanya. Hasil kerja yang dapat dicapai oleh seseorang atau sekelompok orang dalam suatu organisasi sesuai dengan wewenang dan tanggungjawab masing-masing, dalam upaya mencapai tujuan organisasi yang bersangkutan secara legal, tidak melanggar hukum dan sesuai dengan moral etika. 
Sedangkan menurut Suyudi (1999, dikutip dalam Ardiana, Brahmayanti \& Subaedi, 2010:45) kinerja adalah hasil kerja yang dapat dicapai oleh seseorang atau kelompok orang dalam organisasi, sesuai dengan tanggungjawab dan wewenang dalam rangka mencapai tujuan organisasi. Apabila kinerja individu sebagai karyawan baik, maka kemungkinan besar kinerja organisasi atau perusahaan akan baik.

Robbin (2001, dikutip dalam Suprapto, 2009:6) menjelaskan bahwa prestasi kerja atau kinerja akan tercapai apabila karyawan merasa bahwa apa yang dia peroleh dari hasil pekerjaannya telah memenuhi sesuatu yang di anggap menjadi harapan penting atau bahkan melebihi harapan yang diinginkannya.

Menurut Mangkunegara (2009:75), indikator untuk menilai kinerja individu atau karyawan adalah sebagai berikut :

a. Kualitas kerja

Kulitas kerja yaitu seberapa baik seorang karyawan mengerjakan apa yang seharusnya dikerjakan.

b. Kuantitas kerja

Kuantitas kerja yaitu seberapa lama seorang pegawai bekerja dalam satu harinya yang dapat dilihat dari kecepatan kerja masing-masing pegawai.

c. Pelaksanaan tugas

Pelaksanaan tugas yaitu seberapa jauh karyawan mampu melakukan pekerjaannya dengan akurat atau tidak ada kesalahan.

d. Tanggung jawab

Tanggung jawab terhadap pekerjaan yaitu kesadaran akan kewajiban karyawan untuk melaksanakan pekerjaan yang diberikan perusahaan.

\section{Motivasi}

Menurut Mangkunegara (2009:93) motivasi kerja adalah kondisi yang menggerakan pegawai agar mampu mencapai tujuan dari motifnya. Sedangkan menurut Wibowo (2010:379) motivasi adalah dorongan terhadap serangkaian proses perilaku manusia pada pencapaian tujuan. Elemen yang terkandung dalam motivasi meliputi unsur membangkitkan, mengarahkan, menjaga, menunjukkan intensitas, bersifat terus menerus dan adanya tujuan. Dengan demikian motivasi merupakan keinginan seseorang untuk melakukan sesuatu akibat dari dorongan yang berasal dari diri sendiri ataupun dari luar diri pegawai.

Siagian (2008:138) menjelaskan bahwa motivasi adalah daya pendorong yang mengakibatkan seseorang anggota organisasi mau dan rela untuk menggerakkan 
kemampuan dalam membentuk keahlian dan keterampilan tenaga dan waktunya untuk menyelenggarakan berbagai kegiatan yang menjadi tanggung jawabnya dan menunaikan kewajibannya dalam rangka pencapaian tujuan dan berbagai sasaran organisasi yang telah ditentukan sebelumnya . Berdasarkan definisi tersebut dapat dikemukakan bahwa indikator motivasi adalah sebagai berikut:
a. Daya pendorong
b. Kemauan
c. Membentuk keahlian
d. Membentuk keterampilan
e. Tanggung jawab
f. Kewajiban
g. Tujuan

\section{Kompetensi}

Menurut Sudarmanto (2009:87) kompetensi adalah kemampuan dan karekteristik yang dimiliki oleh pegawai negeri sipil yang berupa pengetahuan, keterampilan dan sikap perilaku yang diperlukan dalam pelaksanaan tugas jabatannya sehingga pegawai negeri sipil tersebut dapat melaksanakan tugasnya dengan professional, efektif dan efisien. Sedangkan menurut Harmon (2009:65) kompetensi adalah seperangkat nilai, perilaku, kebijakan, pengelolaan yang dinamis dan struktur yang digunakan oleh orang-orang dalam bekerja yang efektif dengan melibatkan konsumen, stakeholder dan masyarakat.

Lasmahadi (2002, dikutip dalam Safwan, Nadirsyah \& Abdullah, 2014:136) kompetensi didefinisikan sebagai aspek-aspek pribadi dari seorang pekerja yang memungkinkan untuk mencapai kinerja superior. Aspek-aspek pribadi ini mencakup sifat, motif-motif, system nilai, sikap, pengetahuan dan keterampilan dimana kompetensi akan mengarahkan tingkah laku dan tingkah laku akan menghasilkan kinerja.

\section{METODE PENELITIAN Desain Penelitian}

Desain penelitian yang digunakan adalah asosiatif (Sugiyono, 2013, p.11) guna mengetahui hubungan dan pengaruh variabel motivasi dan kompetensi terhadap kinerja pegawai Kantor Pelayanan Pajak Pratama Prabumulih.

Indikator Variabel Kinerja Pegawai (Y): Kualitas kerja, kuantias kerja, pelaksanaan tugas, tanggung jawab 
Indikator Variabel Motivasi (X1): Daya pendorong, kemauan, membentuk keahlian, membentuk tanggung jawab, kewajiban, tujuan

Indikator variabel kompetensi (X2): Sistem nilai, sikap keterampilan, motif pengetahuan, Data dan Metode Pengumpulan Data

Penelitian ini didasarkan pada data primer yang dikumpulkan menggunakan teknik kuesioner. Penelitian dilakukan di Kantor Pajak Pratama Prabumulih yang bertempat di Jalan Jenderal Sudirman No.19, Prabumulih 3114 Sumatera Selatan pada tahun 2015.

\section{Populasi dan Teknik Pengambilan Sampel}

Populasi penelitian ini adalah seluruh pegawai Kantor Pelayanan Pajak Pratama Prabumulih. Berdasarkan data kepegawaian Kantor Pelayanan Pajak Pratam Prabumulih tahun 2014 komposisi dan jumlah/ populasi pegawai yang ada di Kantor Pelayanan Pajak Pratama Prabumulih adalah berjumlah 72 orang pegawai. Teknik pengambilan sampel menggunakan metode teknik probability sampling dan dalam menentukan ukuran sampel menggunakan metode Isaac dan Michael sehingga diperoleh 58 sampel berdasarkan kriteria pendidikan. Berikut pengambilan sammpel dengan kriteria pendidikan:

Tabel 4. Pengambilan sampel berdasarkan tingkat pendidikan pegawai

\begin{tabular}{clc}
\hline $\begin{array}{c}\text { Tingkat } \\
\text { Pendidikan }\end{array}$ & \multicolumn{1}{c}{ Populasi } & Total Sampel \\
\hline S2 & $12 / 72 \times 58=9.67$ & 10 \\
S1 & $22 / 72 \times 58=17.72$ & 18 \\
DIV & $4 / 72 \times 58=3.22$ & 3 \\
DIII & $23 / 72 \times 58=18.52$ & 18 \\
DI & $5 / 72 \times 58=4.02$ & 4 \\
SMA & $6 / 72 \times 58=4.83$ & 5 \\
\hline Total & & 58 \\
\hline
\end{tabular}

Sumber: Kantor Pelayanan Pajak Prabumulih, data diolah tahun 2015

\section{HASIL PENELITIAN DAN PEMBAHASAN \\ Hasil Penelitian}

\section{Uji normalitas}

Uji normalitas menggunakan Kolmogorov smirnov yang memiliki kelebihan sederhana dan tidak menimbulkan perbedaan persepsi di antara satu pengamat dengan pengamat 
yang lain, yang sering terjadi pada uji normalitas dengan menggunakan grafik. Hasil uji normalitas data menunjukkan hasil sebagai berikut: Nilai Asymp.sig. (2-tailed) untuk Motivasi (X1) sebesar 0.266, Nilai Asymp.sig. (2-tailed) untuk kompetensi (X2) sebesar 0.115, Nilai Asymp.sig. (2-tailed) untuk Kinerja (Y) sebesar 0.208. Semuanya menunjukkan hasil di atas 0,05 maka distribusi data, motivasi (X1), kompetensi (X2) dan Kinerja Pegawai (Y) diasumsikan memenuhi normalitas.

\section{Analisis Regresi Berganda}

Dari hasil regresi berganda yang menggunakan program SPSS for Window versi 20 pada variabel, untuk mengetahui pengaruh Motivasi (X1) dan kompetensi (X2) terhadap Kinerja pegawai (Y) adalah menunjukkan nilai beta pada Unstandardized Coefficients untuk konstanta 75,455, untuk motivasi $(\mathrm{X} 1)=-0,256$; dan untuk kompetensi $(\mathrm{X} 2)=0,275$ dapat disusun persamaan sebagai berikut:

$$
\mathrm{Y}=75.455-0.256 \mathrm{X}_{1}+0.275 \mathrm{X}_{2}
$$

Dari persamaan regresi berganda di atas, dapat diterangkan sebagai berikut:

1) Nilai konstanta sebesar 75.455. hal ini menunjukkan bahwa apabila variabel motivasi (X1) dan kompetensi (X2) nilainya nol maka nilai kinerja adalah 75.455

2) Nilai koefisien regresi motivasi (X1) adalah sebesar -0.256. hal ini menunjukkan bahwa apabila nilai motivasi (X1) meningkat 1 satuan atau $100 \%$ maka nilai variabel kinerja pegawai (Y) akan mengalami penurunan sebesar 0.256 dengan asumsi variabel independen lainnya konstan.

3) Nilai regresi kompetensi $\left(\mathrm{X}_{2}\right)$ adalah sebesar 0.257. hal ini menunjukkan bahwa apabila nilai kompetensi (X2) meningkat 1 satuan atau $100 \%$ maka nilai variable kinerja pegawai (Y) akan mengalami kenaikan sebesar 0.257 dengan asumsi variabel independen lainnya konstan. Dengan adanya pengaruh positif ini, berarti kompetensi dan kinerja pegawai menunjukkan hubungan yang searah. Jika variabel kompetensi meningkat maka kinerja pegawai akan meningkat, begitupula sebaliknya jika kompetensi menurun maka kinerja pegawai akan semakin menurun.

\section{Uji Koefisien Determinan}

Nilai R square (koefisien determinasi) pada Model Summary menunjukkan angka: 0,166 yang artinya $16.6 \%$ kinerja pegawai yang terjadi dapat dijelaskan dengan menggunakan variabel motivasi dan kompetensi, sedangkan $83.4 \%$ dapat dijelaskan oleh factor-faktor penyebab lainnya. Nilai standard error of the estimate (SEE) untuk kinerja pegawai sebesar 1.449.jika dibandingkan dengan angka standard deviation (STD) sebesar 1.559, maka angka SEE lebih kecil yang berarti angka SEE baik untuk dijadikan angka predictor dalam menentukan kinerja pegawai 


\section{Uji Hipotesis}

Uji F

Uji $\mathrm{F}$ atau signifikansi serentak dimaksudkan untuk melihat pengaruh motivasi (X1) dan kompetensi (X2) secara bersama-sama terhadap kinerja pegawai (Y). Hasil print out didapatkan sig 0.007 maka $<0.05$ sehingga Ho ditolak. $\mathrm{F}$ tabel $(\mathrm{VI}=\mathrm{k}, \mathrm{V} 2=\mathrm{n}-$ $\mathrm{k}-1)$ jadi (VI=3, V2=2.78) maka F hitung untuk variabel motivasi (X1) dan kompetensi (X2) terhadap kinerja pegawai $(\mathrm{Y})$ adalah sebesar 5.460, dengan demikian $\mathrm{F}$ hitung (5.460) > F tabel (2.78) hal ini berarti ada pengaruh motivasi dan kompetensi secara bersama-sama terhadap kinerja pegawai Kantor Pelayanan Pajak Pratama Prabumulih.

\section{Uji t}

Uji t atau signifikansi parsal digunakan untuk menguji apakah suatu variabel bebas berpengaruh atau tidak terhadap variabel terikat (suharyadi \& Purwanto, 2013, p.228). dalam penelitian ini uji t untuk melihat pengaruh motivasi (X1) dan kompetensi (X2) secara parsial terhadap kinerja pegawai (Y)

Menurut Sujarweni (2014), jika sig t > 0.05 maka tidak ada pengaruh yang signifikan dan jika sig $\mathrm{t}<0.05$ maka ada pengaruh yang signifikan. Berdasarkan tabel diatas dapat dilihat bahwa:

a) Nilai signifikan untuk motivasi $\left(\mathrm{X}_{1}\right)$ sebesar 0.018 yang berarti sig t $(0.018)<\mathrm{a}$ (0.05). Hal tersebut menggambarkan bahwa ada pengaruh motivasi (X1) secara parsial terhadap kinerja pegawai (Y) Kantor Pelayanan Pajak Pratama Prabumulih.

b) Nilai signifikan untuk kompetensi (X2) sebesar 0.009 yang berarti sig t (0.009) < a (0.05). Hal tersebut menggambarkan bahwa ada pengaruh kompetensi (X2) secara parsial terhadap kinerja pegawai (Y) Kantor Pelayanan Pajak Pratama Prabumulih

\section{SIMPULAN DAN SARAN}

\section{Simpulan}

Berdasarkan hasil penelitian mengenai pengaruh motivasi dan kompetensi terhadap kinerja pegawai Kantor Pelayanan Pajak Pratama Prabumulih, dapat diambil kesimpulan sebagai berikut: 1) Hasil pengujian secara bersama-sama (simultan) menunjukkan ada pengaruh yang signifikan antara motivasi dan kompetensi terhadap kinerja pegawai. 2) Hasil pengujian secara parsial variabel motivasi dan kompetensi memberikan pengaruh yang signifikan terhadap kinerja pegawai Kantor Pelayanan Pajak Pratama Prabumulih. 


\section{Saran}

Dari hasil penelitian dapat disarankan: 1) Sebaiknya pegawai perlu diberikan reward oleh pimpinan jika mampu mencapai/ melebihi batas target dalam memungut pajak dari wajib pajak agar pegawai termotivasi untuk mencapai kinerja superior. 2) Sebaiknya diberikan sanksi kepada wajib pajak yang menghindar dari pendataan wajib pajak. 3) Bagi peneliti yang akan melakukan penelitian lebih lanjut sebaiknya menambahkan variabel yang akan diteliti seperti dispilin kerja, lingkungan kerja atau variable lainnya sehingga dapat memperkaya kajian faktor yang memengaruhi kinerja pegawai Kantor Pelayanan Pajak Pratama Prabumulih.

\section{DAFTAR PUSTAKA}

Ardiana, Brahmayanti \& Subaedi. 2010. Kompetensi SDM UKM dan Pengaruhnya Terhadap Kinerja UKM di Surabaya. Jurnal Manajemen dan Kewirausahaan, 2(1),45.

Harmon. 2009. Pengaruh Kompetensi Individu Front Office Terhadap Kualitas Pelayanan. Jurnal Manajemen dan Bisnis, 6 (1), 65.

Mangkunegara, AP. 2009. Manajemen Sumber Daya Manusia Perusahaan. Bandung, Indonesia: Refika Aditama

Rusdy A, Rifai. 2009. Manajemen Cetakan Kedua Edisi 2. Palembang: Lembaga Penerbit Fakultas Ekonomi Universitas Muhammadiyah Palembang.

Sedarmayanti. 2007. Manajemen Sumber Daya Manusia. Bandung, Indonesia: Refika Aditama

Siagian. 2008. Manajemen Sumber Daya Manusia. Jakarta, Indonesia: Bumi Aksara

Sudarmanto. 2009. Kinerja dan Pengembangan Sumber Daya Manusia. Yogyakarta, Indonesia: Pustaka Pelajar.

Sugiyono. 2013. Metode Penelitian Manajemen. Bandung, Indonesia: Alfabeta

Sujarweni, Wiratna. 2014. SPSS Untuk Penelitian. Yogyakarta, Indonesia: Pustaka Baru Press.

Suparno \& Sudarwati. 2014. Pengaruh Motivasi, Displin Kerja dan Kompetensi terhadap Kinerja Pegawai Dinas Pendidikan Kabupaten Sragen. Jurnal Paradgima, 12(1), 21.

Suprapto. 2009. Pengaruh Kompetensi dan Motivasi Terhadap Kinerja Pegawai Dengan Kepuasan Sebagai Moderating Variabel. Jurnal Manajemen, 1(1), 6.

Wibowo. 2010. Manajemen Kinerja. Jakarta, Indonesia: Raja Grafindo Persada. 